\title{
ANALISIS FUNGSI-FUNGSI MANAJEMEN SUMBER DAYA MANUSIA PADA BEBERAPA PERUSAHAAN BUMN DI KOTA MEDAN
}

\author{
Hilma Harmen ${ }^{1}$, Fauzia Agustini' ${ }^{2}$, Aprinawati ${ }^{3}$, Dita Amanah ${ }^{4}$ \\ 1) Program Studi Manajemen, Fakultas Ekonomi, Unimed \\ E-mail: hilmaharmen@gmail.com ${ }^{1)}$, fauziaagustini@yahoo.com ${ }^{2)}$, aprinawati77@gmail.com ${ }^{3)}$, \\ ditamnh@yahoo.com ${ }^{4}$
}

\begin{abstract}
Abstrak
Penelitian ini bertujuan untuk mengetahui fungsi-fungsi manajemen sumber daya manusia di perusahaan Badan Usaha Milik Negara di Kota Medan yakni PT. PELINDO 1, PT Bhanda Ghara Reksa, dan PT BPJS Ketenagakerjaan Cabang Tanjung Morawa Sumatera Utara. Adapun metode yang dilakukan dalam penelitian ini adalah penelitian kualitatif dengan pengumpulan data dengan wawancara, daftar pertanyaaan, observasi, studi kepustakaan. Peneliti telah mendapatkan pengetahuan tentang tugas-tugas bagian SDM pada ketiga perusahaan lebih jelas, lengkap, dan terperinci dibandingkan dengan pengetahuan yang diperoleh dari literatur, seperti misalnya fungsi analisis jabatan pada PT. PELINDO 1 telah menguraikan analisis jabatan yang lebih detail bagaimana job description dan job specification pada perusahaan tersebut.
\end{abstract}

Kata Kunci : Fungsi-fungsi manajemen sumber daya manusia, Badan Usaha Milik Negara. 


\section{PENDAHULUAN}

Manajemen sumber daya manusia (MSDM) merupakan salah satu bidang dari manajemen umum yang meliputi segi-segi perencanaan, pengorganisasian, pelaksanaan dan pengendalian (Veithzal: 2009).

Manajemen sumber daya manusia merupakan kegiatan yang mengatur tentang cara pengadaan tenaga kerja, melakukan pengembangan, memberikan kompensasi, pemeliharaan, dan pemisahan tenaga kerja melalui proses-proses manajemen dalam rangka mencapai tujuan organisasi (Yuli: 2005).

Manajemen sumber daya manusia meliputi atas proses perencanaan, pengorganisaisan, pimpinan serta pengendalian segala aktivitas yang masih berkaitan dengan analisa pekerjaan, evaluasi atas pekerjaan, pengadaan, pengembangan, promosi, kompensasi serta pemutusan hubungan kerja untuk mencapai tujuan yang diinginkan (Panggabean, 2004).

Berdasarkan pengertian Manajemen SDM tersebut, maka dapat disimpulkan bahwa pembahasan manajemen sumber daya manusia tidak terlepas dari fungsi-fungsi Manajemen SDM yang terdiri dari menganalisis pekerjaan dan jabatan, merencanakan SDM di perusahan, melakukan perekrutan tenaga kerja, menseleksi calon tenaga kerja, melakukan orientasi dan penempatan kerja, melatih karyawan, melakukan penilaian karyawan, melakukan kebijakan kompensasi, melaksanakan kegiatan pengembangan dan perencanaan karir, serta membuat kebijakan pemutusan hubungan kerja. Fungsi-fungsi Manajemen SDM ini adalah merupakan tugas-tugas bagian SDM dalam perusahaan.

Selama ini peneliti mendapatkan pengetahuan tentang fungsi-fungsi Manajemen SDM atau tugas-tugas bagian SDM tersebut terbatas hanya secara teori yang didapatkan dari literatur berupa buku maupun artikel terkait. Hal ini membuat peneliti ingin mengetahui lebih jelas tentang fungsi-fungsi MSDM dalam perusahaan secara langsung di perusahaan sehingga peneliti dapat kondisi nyata apa yang menjadi tugas-tugas bagian SDM dalam perusahaan serta menambah wawasan dan pengetahuan tentang fungsi-fungsi MSDM tersebut.

Penelitian ini dilakukan pada tiga (3) perusahaan BUMN di Kota Medan yaitu PT BPJS Ketenagakerjaan Cabang Tanjung Morawa
NIAGAWAN Vol 8 No 3 November 2019 Sumatera Utara, PT Bhanda Ghara Reksa, dan PT. PELINDO 1. Adapun alasan peneliti memilih BUMN sebagai tempat penelitian disebabkan BUMN telah merupakan perusahaan terpercaya yang memiliki Standard Operational Procedure yang sudah baku. Hal inilah yang membuat ketertarikan peneliti melakukan penelitian tentang fungsi-fungsi MSDM atau tugas-tugas bagian SDM pada ketiga perusahaan BUMN di Kota Medan.

Adapun yang menjadi tujuan dalam penelitian ini agar dapat mengaitkan teori manajemen SDM dengan kondisi nyata dalam perusahaan..

\section{METODE PENELITIAN \\ Lokasi Penelitian}

Penelitian ini dilaksanakan pada 3 (tiga) perusahaan di kota Medan yaitu di PT. PELINDO 1, PT. Bhanda Ghara Reksa, dan PT. BPJS Ketenagakerjaan.

\section{Jenis Penelitian}

Penelitian ini merupakan penelitian kualitatif.

\section{Teknik Pengumpulan Data}

Adapun teknik pengumpulan data dalam penelitian ini menggunakan:

1. Wawancara.

Yaitu mengadakan Tanya jawab kepada pihak perusahaan tentang fungsi-fungsi Manajemen SDM.

2. Daftar pertanyaaan.

Berisikan pertanyaan-pertanyaan yang terkait dengan fungsi-fungsi Manajemen SDM dalam perusahaan.

\section{Observasi}

Yaitu berupa pengamatan langsung ke perusahaan.

\section{Studi Kepustakaan}

Yaitu berupa literature yang didapat dari buku, jurnal dan internet yang terkait dengan penelitian ini. 


\section{PEMBAHASAN}

\section{Fungsi-fungsi Manajemen SDM/ Tugas- Tugas Bagian SDM Pada Perusahaan}

Pada penelitian ini, fungsi-fungsi manajemen SDM pada perusahaan telah dibagi ke dalam 10 tugas. Peneliti sudah melakukan wawancara dengan tiga perusahaan yaitu PT Pelindo I, PT Bhanda Ghara Reksa, dan PT BPJS Ketenagakerjaan Cabang Tanjung Morawa. Adapun hasil wawancara yakni sebagai berikut:

\section{a. Analisis Jabatan Pada PT Pelindo I}

Analisis pekerjaan Menurut Cushway (2002) adalah : "Suatu proses yang digunakan untuk menentukan dan menggambarkan isi pekerjaan sedemikian rupa hingga gambaran yang jelas mengenai pekerjaan itu dapat disampaikan kepada orang yang memerlukan informasi untuk tujuan manajemen".

\section{Identitas Jabatan}

Menggambarkan identitas suatu jabatan, biasanya mencakup nama jabatan, kelompok jabatan, bagian/departemen/divisi dimana jabatan berada, kode jabatan, nama jabatan atasan, lokasi.

2. Kedudukan dalam Organisasi

Menggambarkan posisi-posisi yang berada di atas, di bawah, dan setara dengan jabatan ini dalam satu bagian organisasi.

3. Fungsi Utama

Uraian yang menjelaskan tujuan/alasan diciptakannya jabatan tersebut, apa kontribusi jabatan tersebut. Menjawab pertanyaan "mengapa jabatan tersebut diperlukan?"

\section{Tanggung Jawab}

Menjawab pertanyaan "Kondisi apa yang harus diciptakan oleh jabatan tersebut?" atau "Proses apa yang harus dipastikan berjalan oleh jabatan tersebut?". Dapat merupakan bentuk dari pendelegasian tugas dari atasan kepada bawahannya.

5. Tugas Pokok (Uraian Tugas)

Menjelaskan tugas/kegiatan yang harus dilakukan oleh jabatan/posisi tersebut dalam rangka mencapai tujuan/fungsi dari jabatan. Menjawab pertanyaan "apa yang dilakukan oleh posisi tersebut?”
NIAGAWAN Vol 8 No 3 November 2019

\section{Wewenang}

Menjelaskan hak yang dimiliki oleh jabatan untuk mengambil suatu keputusan atau tindakan agar tugas pokok yang dilaksanakan dapat berhasil dengan baik dan memastikan otoritas yang cukup dalam batasan ruang lingkup tugasnya.

Menjelaskan apa yang dapat diputuskan oleh jabatan tersebut terhadap tugas yang dijalankannya. Menjawab pertanyaan "wewenang apa yang diperlukan oleh jabatan dalam melakukan tugasnya?"

\section{Indikator Kinerja}

Menggambarkan bagaimana kinerja dari pemegang jabatan akan dinilai. Mengukur keberhasilan dari pencapaian "mengapa" pada setiap tugas. Menganut prinsip indikator yang SMART, kuantitatif, mengukur hasil bukan mengukur aktifitas.

\section{Dimensi Jabatan}

Menggambarkan besarnya cakupan jabatan, baik langsung maupun tidak langsung, yang dapat membedakan antara suatu jabatan dengan jabatan lain yang setingkat. Dapat berupa jumlah bawahan, area cakupan wilayah tugas, lingkup target.

9. Hubungan Kerja

Menjelaskan

nama posisi/jabatan/unit kerja/institusi yang terkait dalam menjalankan tugasnya dan dalam hal apa huungan kerja tersebut dilakukan. Memberikan gambaran pihak-pihak yang mempengaruhi jalannya tugas, pencapaian kinerja dan kuaitas produk yang dihasilkan. Menjawab pertanyaan "dengan siapa saja pemangku jabatan berhubungan dalam menjalankan tugasnya?"

\section{Persyaratan Jabatan}

Menjelaskan kualifikasi yang harus dimiliki oleh pemangku jabatan yang dapat berupa kepangkatan, pendidikan formal, kursus, pengalaman kerja, pengetahuan, kemampuan teknis (hard/technical competency), perilaku (soft competency) dan persyaratan lainnya.

\section{Produk Jabatan}

Menjelaskan produk atau keluaran dari jabatan tersebut, memberikan gambaran kontribusi jabatan secara lebih 
NIAGAWAN Vol 8 No 3 November 2019

spesifik terhadap organisasi. Menjawab pertanyaan "apa yang dihasilkan dari pelaksanaan tugas jabatan tersebut?"

Pada Perusahaan Pelindo I dalam membuat persyaratan jabatan, pertama harus mengetahui fungsi utama jabatan tersebut. Kemudian menentukan apasaja tanggunggung jawab dari tugas tesebut, selanjutnya menentukan tugas-tugas pokok dari jabatan tersebut. Dari tugas pokok tersebut akan ditentukan wewenang, produk yang dihasilkan dari jabatan tersebut, indikator kinerja, dan hubungan kerja.

\section{b. Perencanaan SDM Pada PT Pelindo I}

Sikula (2001) mengemukakan bahwa perencanaan sumber daya manusia atau perencanaan tenaga kerja didefinisikan sebagai proses menentukan kebutuhan tenaga kerja dan berarti mempertemukan kebutuhan tersebut agar pelaksanaannya berinteraksi dengan rencana organisasi.

Adapun Performance Management pada PT Pelindo I, yang pertama melakukan perencaan dengan formulasi strategi, memahami kepentingan para stakeholder, menganalisis dinamika pasar, dan menentukan strategi dan ukuran keberhasilan. Selanjutnya eksekusi strategi yang terdiri dari mengkomunikasikan rencana dan strategi, menyelaraskan tujuan dan ukuran antar unit bisnis, dan mengalokasikan sumber daya. Kemudia melakukan analisis yang terdiri dari Track Progress, perkiraan kinerja, dan menganalisis scenario alternative. Tahapan terakhir yaitu review dan optimasi, terdiri dari review performa, memperbaiki strategi dan rencana strategi, dan identifikasi action plan.

1. Penyusunan Key Performance Indicator (KPI)

Penyusunan KPI didasarkan pada strategi bisnis perusahaan, tujuan utama yang ingin dicapai oleh suatu perusahaan. Untuk menyusun KPI, perusahaan harus menentukan strategi bisnis dan apa yang ingin dicapai oleh perusahaan, kemudian rencana jangka panjang dan jangka pendek dalam pencapaian strategi, langkah penting dalam mengeksekusi strategi dan tujuan utama, selanjutnya ukuran kesuksesan dan terakhir rincian langkah yang mendukung KPI.

2. Faktor Penting Penyusunan KPI

a. KPI harus memiliki keterkaitan dengan strategi bisnis, hal yang dianggap paling penting oleh perusahaan

b. Memberikan jawaban terhadap permasalahan penting dalam perusahaan

c. KPI di design untuk mengoptimalkan karyawan dan memberikan informasi yang relevan

\section{GOOD KPI's}

- Menyesuaikan dengan tujuan organisasi

- Membuat makna dalam setiap level

- Berdasarkan pada data yang sah

- Membangun tren dari waktu ke waktu

- Mudah dimengerti dan memiliki konteks

- Berujung pada tindakan

\section{c. Perekrutan Karyawan Pada PT Pelindo I}

Proses rekrutmen adalah suatu proses penerimaan calon tenaga kerja untuk memenuhi kebutuhan akan tenaga kerja (lowongan pekerjaan) pada suatu unit kerja dalam suatu organisasi atau perusahaan (Cascio, 2003)

Proses perekrutan pada PT Pelindo I diadakan oleh kantor strategic bukan pada kantor cabang. Adapun persyaratan seorang karyawan direkrut adalah diawali dengan persyaratan umum, yakni kemampuan Bahasa Inggris yan dibuktikan dengan Test TOEFL, berpenampilan menarik, uji psikotes, dan tes wawasan kebangsaan serta tes bakat dan minat calon karyawan.

\section{d. Seleksi Karyawan Pada PT Bhanda Ghara Reksa}

Seleksi adalah suatu proses menyaring para pelamar guna memilih yang terbaik untuk diterima bekerja di perusahaan. Penyaringan adalah proses pemisahan 
individu yang paling besar kemungkinan akan berhasil dalam suatu pekerjaan dan cocok masuk organisasi, dari individu lain dari sejumlah besar pelamar. Jika proses ini mengurangi sejumlah besar pelamar sampai tinggal satu pelamar, penyaringan menjadi sama dengan seleksi (Agustini dan Harmen: 2018)

1. Proses seleksi yang ada di dalam perusahaan

Proses seleksi sesuai dengan kebutuhan perusahaan. Sebelumnya, seleksi melalui publikasi media cetak, lalu ditetapkan persyaratan calon karyawan. Dimulai seleksi administrasi, seleksi fisik, wawancara awal, lalu mengikuti tes psikologi di Universitas Sumatera Utara (USU) dan Universitas Negeri Medan (Unimed) untuk pengarahan kesesuaian penempatan kerja dan menilai calon karyawan pada tiga kategori (memiliki kemampuan, dipertimbangkan, tidak dipertimbangkan). Setelah pengiriman data ke Kantor Pusat, lalu wawancara dengan pihak manajemen dan akan ada pengkategorian kembali yakni diterima, dipertimbangkan, dan tidak layak diterima. Jika layak diterima akan ada kontrak kerja dengan gaji sesuai UU Ketenagakerjaan dan UMR. Kontrak kerja maksimal selama 3 (tiga) tahun. Jika setelah 3 tahun, karyawan sesuai dengan kebutuhan manajemen maka akan diangkat menjadi karyawan tetap perusahaan. Namun ketika tidak sesuai maka tidak akan diangkat menjadi karyawan tetap perusahaan.

2. Teknik seleksi yang digunakan di dalam perusahaan.

Teknik seleksi akan disesuaikan dengan kebutuhan perusahaan. Umumnya, setiap tahun perusahaan membuat anggaran dan perencanaan, setiap departemen merencanakan kebutuhan calon karyawan. Ketika karyawan akan pensiun, maka perusahaan akan mempersiapkan calon pengganti selama kurang lebih satu tahun dan akan di rekrut ketika karyawan setelah pensiun.

\section{e. Orientasi dan Penempatan Karyawan Pada PT Bhanda Ghara Reksa}

Orientasi merupakan suatu program untuk memperkenalkan pegawai baru pada peran-peran mereka, organisasi, kebijaksanaan - kebijaksanaan, nilai - nilai, keyakinan - keyakinan, dan pada rekan kerja mereka. (Hariandja, 2002).

1. Waktu orientasi kerja yang diperlukan dalam perusahaan.

Ketika karyawan direkrut melalui koperasi, maka tidak perlu orientasi. Ketika direkrut dari pihak eksternal perusahaan, maka akan ada orientasi ketika mulai bekerja. Namun, pada manajemen Kantor Pusat jabatan strategis, akan ada orientasi sebelum bekerja selama kurang lebih 1 tahun. Selama 6 bulan diadakan pendidikan teori dan selama 6 bulan selanjutnya akan diadakan pendidikan praktek dan penempatan langsung pada seluruh departemen perusahaan.

2. Jenis orientasi apa saja yang digunakan dalam perusahaan.

Orientasi yang digunakan yakni pada jabatan strategis maka orientasi sebelum masa kerja dan pada jabatan non strategis maka orientasi ketika masa kerja.

3. Perusahaan meninjau materi orientasi secara berkala.

Perusahaan melaksanakan peninjauan orientasi secara berkala. Yang melaksanakan peninjauan ialah tim ahli dari pihak internal dan eksternal perusahaan., seperti dari pihak akademisi.

4. Perusahaan melakukan penempatan karyawan bagi karyawan baru.

Karyawan akan ditempatkan sesuai dengan kebutuhan perusahaan sesuai dengan bakat dan kemampuan karyawan dan kebutuhan perusahaan.

5. Perusahaan menentukan penempatan bagi karyawan lama yaitu Promosi, demosi, dan transfer atau mutasi.

Untuk promosi, direktur utama akan merencanakan penggantian jabatan strategis ketika akan pensiun dan akan diberikan pendidikan ilmu manajerial pada 
manajemen Kantor Pusat. Untuk demosi, apabila karyawan melakukan kegiatan 'indisipliner' maka akan dilaksanakan demosi. Untuk mutasi dan transfer, dapat dilakukan karena sesuai kebutuhan dan secara berkala. Ketika karyawan telah menduduki jabatan selama 5 tahun maka akan dilaksanakan mutasi atau transfer.

\section{f. Pelatihan Kerja Pada PT Bhanda Ghara Reksa}

Pelatihan menurut Dessler (2003) adalah proses mengajarkan karyawan baru atau yang ada sekarang, ketrampilan dasar yang mereka butuhkan untuk menjalankan pekerjaan mereka. Pelatihan merupakan "serangkaian aktivitas yang memberikan kesempatan untuk mendapatkan dan meningkatkan ketrampilan yang berkaitan dengan pekerjaan”.

1. Perusahan menganalisis kebutuhan pelatihan bagi karyawan baru dan karyawan lama.

Pelatihan dilaksanakan pada karyawan baru dan karyawan lama. Perusahaan menganggarkan biaya khusus untuk pelatihan. Analisis sesuai kebutuhan departemen perusahaan. Untuk keuangan, biasanya akan ada pelatihan perpajakan bagi karyawan.

2. Metode pelatihan apa saja yang diberikan perusahaan kepada karyawan.

Pelatihan dapat dilakukan dari intenal perusahaan pada departemen keuangan maupun eksternal perusahaan seperti pada aliansi perpajakan dan lain-lain.

3. Cara perusahaan mengetahui manfaat pelatihan tersebut baik dari sisi perusahaan maupun karyawan.

Cara mengetahui manfaat pelatihan umumnya dinilai dalam tiga atau empat bulan. Diketahui melalui pola kerja dan pengetahuan karyawan. Tim penilai adalah bagian SDM perusahaan. Ketika karyawan perusahaan masih belum maksimal
NIAGAWAN Vol 8 No 3 November 2019 menerima pelatihan maka akan mendapatkan pelatihan tambahan.

\section{g. Penilaian Kinerja Pada PT BPJS Ketenagakerjaan Cabang Tanjung Morawa}

Penilaian kinerja menurut Mondy (2008) merupakan suatu sistem formal yang secara berkala digunakan untuk mengevaluasi kinerja individu dalam menjalankan tugastugasnya.

1. Elemen-elemen yang diukur dalam Penilaian Kinerja Karyawan antara lain:

a) KPI Balance Scorecard

b) $\mathrm{KBI}$

a. Achievement Orientation = Kemampuan mamperoleh hasil melebihi standar.

b. Customer Service Excellence = Mengerti dan memahami kebutuhan pelanggan secara utuh.

c. Continuous Learning \& Improvement $=$ Kemauan belajar dan memiliki inisiatif dan inovasi.

d. Profesionalisme $=$ Bertindak sesuai dengan budaya dan nilai-nilai iman ETHIKA (Ekselen, Teladan, Harmoni, Integritas, Iman, Kepedulian, dan Antusias)

e. Synergi Building = Mampu bekerjasama dengan tim lain.

2. Metode yang digunakan adalah Comparative Evaluation Approach yaitu dengan menggunakan metode peringkat dengan cara membandingkan kinerja karyawan dari yang paling tinggi sampai yang paling rendah.

3. 4 kali per triwulan

4. Kalau dalam menilai KPI tidak mungkin ada hallo effect, tapi kalau di KBI itu bisa terjadi tetapi itu kembali kepada individu masing-masing.

5. Berupa bonus dan insentif.

h. Kompensasi Pada PT BPJS Ketenagakerjaan Cabang Tanjung Morawa 
NIAGAWAN Vol 8 No 3 November 2019

Kompensasi meliputi bentuk pembayaran tunai langsung, pembayaran tidak langsung dalam bentuk manfaat karyawan, dan insentif untuk memotivasi karyawan agar bekerja keras untuk mencapai produktivitas yang semakin tinggi (Cascio, 2003).

1. Berdasarkan presentase

2. Bonus, insentif, reward ke luar negeri dan naik golongan dipercepat

3. Sangat berhubungan karena kompensasi diberikan berdasarkan nilai dari karyawan tersebut, semakin baik nilainya maka semakin besar kompensasi yang diterima.

\section{i. Perencanaan dan Pengembangan Karir Pada PT BPJS Ketenagakerjaan Cabang Tanjung Morawa}

Pengembangan karyawan adalah suatu usaha untuk meningkatkan kemampuan teknis, teoritis, konseptual, dan moral karyawan/pegawai sesuai dengan kebutuhan pekerjaan/jabatan melalui pendidikan dan latihan (Hasibuan 2000).

1. Memberi kesempatan untuk mengikuti pendidikan teknis dan non teknis

2. Lulus mengikuti diklat antara lain:
a. Basic Leadership Development Program (BLDP)
b. Intermediate Leadership
Development Program (ILDP)
c. Advance Leadership Development Program (ALDP)

3. Tidak selalu berhubungan, karena ada persyaratan lain yaitu masa kerja, golongan dan grade dan tentu saja ada usulan dari kepala kantor.

\section{j. Pemutusan Hubungan Kerja Pada PT BPJS Ketenagakerjaan Cabang Tanjung Morawa}

Pemutusan hubungan kerja adalah keadaan yang mungkin terjadi dalam perusahaan, yang dapat disebabkan oleh berbagai macam alasan seperti disiplin, ekonomi, bisnis, dan alasan-alasan pribadi (Hariandja, 2002).

1. PHK secara terhormat dan tidak terhormat

PHK secara terhormat, usia sudah memasuki usia pensiun saat ini 57 tahun. Sedangkan yang tidak terhormat, ini biasanya karyawan melakukan kesalahan baik kesalahan moral ataupun terjadi fraud. Prosedur yang dilakukan oleh Divisi Satuan Pengawasan Internal (SPI) Kantor Pusat, apabila terbukti maka akan dibawa kepada Badan Pertimbangan Pegawai yang meliputi unsur Human Capital, Serikat Pekerja, SPI dan hasilnya dibawa ke Direksi untuk diambil keputusan.

\section{KESIMPULAN DAN SARAN}

Penelitian telah dilakukan di PT. PELINDO 1, PT. Bhanda Ghara Reksa, dan PT. BPJS Ketenagakerjaan. Adapun kesepuluh fungsi-fungsi MSDM telah dibagi kedalam tiga tempat. Untuk fungsi analisis jabatan, perencanaan SDM dan perekrutan karyawan dilaksanakan di PT. PELINDO 1, kemudian untuk fungsi seleksi karyawan, orientasi dan penempatan karyawan, dan pelatihan kerja dilaksanakan di PT. Bhanda Ghara Reksa, selanjutnya untuk fungsi penilaian kinerja, kompensasi, perencanaan dan pengembangan karir, dan pemutusan hubungan kerja dilaksanakan di PT. BPJS Ketenagakerjaan.

Peneliti telah mendapatkan pengetahuan tentang tugas-tugas bagian SDM pada ketiga perusahaan lebih jelas, lengkap, dan terperinci dibandingkan dengan pengetahuan yang diperoleh dari literatur, seperti misalnya fungsi analisis jabatan pada PT. PELINDO 1 telah menguraikan analisis jabatan yang lebih detail bagaimana job description dan job specification pada perusahaan tersebut.

Hendaknya pihak Universitas dan Fakultas memiliki hubungan yang baik dengan pihak stakeholder sehingga peneliti dapat dengan mudah bekerjasama dengan para stakeholder tersebut. 


\section{REFERENSI}

Manajemen Sumber Daya Manusia. Medan: Pusat Studi Sejarah dan Ilmu Sosial Unimed.

Cascio, W.F. 2003. Managing Human Resources: Productivity, Quality of Work Life, Profits (6th Ed.). Boston: McGraw-Hill Irwin.

Cushway, B. 2002. Manajemen Sumber Daya Manusia. Elex Media Komputindo, Jakarta

Dessler, Gary. 2003. Human Resource Management, Tenth Edition. New Jersey : Prentice Hall.

Hariandja, T.E Marihot. 2002. Manajemen

Sumber Daya Manusia, Jakarta : PT.

Grasindo.

Hasibuan, S.P Malayu. 2002. Manajemen Sumber Daya Manusia, Edisi Revisi, Jakarta : Bumi Aksara.

Mondy, R. Wayne. 2003. Human Resources Management. New Jersey: Prentice Hall.

Panggabean, S., Mutiara. 2004. Manajemen

Sumber Daya Manusia. Bogor: Ghalia Indonesia.

Sikula,. Andrew E. 2000. Manajemen Sumber Daya Manusia. Erlangga. Bandung.

Veithzal. Rivai. 2009. Manajemen Sumber Daya Manusia Untuk Perusahaan. Dari Teori ke Praktik. Jakarta: Raja Grafindo Persada.

Yuli, Sri Budi, 2005. Manajemen Sumber

Daya Manusia. Malang: UMM Press.

Www.peraturan.go.id. Undang-Undang Nomor 19 Tahun 2003. Diakses pada tanggal 19 Desember 2018 